\title{
Review on Water and Pasture Resources in Pastoral Area of Southern Ethiopia: Management, Status and Challenges
}

\author{
Brook Legese ${ }^{1} \quad$ Daniel Duba $^{2} \quad$ Dengelatu Assefa ${ }^{3}$ \\ 1.Department of Natural Resources Management, Bule Hora University, Ethiopia \\ 2.Department of Plant Science, Bule Hora University, Ethiopia \\ 3.Department of Animal and Range Science, Bule Hora University, Ethiopia
}

\begin{abstract}
Rely on mobility and flexibility, the pastoral system optimizes the use of natural resources to maintain the livestock on which pastoralists depend for their well-being. As per review, in the case of the pastoralists of southern Ethiopia, however, numerous pressures, including poor policies, agricultural encroachment, and population pressure and land degradation are now undermining the resilience of the system and of the natural resource base. Moreover, both formal and informal institutions have been playing critical role in management of commons (water and pasture). But, this excellent system of resource management have been weakened gradually with influence of different external factors like; state intervention, privatizations of communal lands and marginalization of indigenous knowledge of community. Various strategies are being employed by NGOs to support the livelihoods of pastoralists in southern Ethiopia. Since livestock is the basis of their livelihoods, an invaluable component of any intervention activity is to improve the condition of, and with its access to, water and pasture so that livestock can be maintained. To do so understand the rangeland context for effective planning is vital.
\end{abstract}

Keywords: Water, Pasture, Pastoralist, Rangeland

DOI: $10.7176 / \mathrm{JRDM} / 65-02$

Publication date:May $31^{\text {st }} 2020$

\section{Introduction}

The pastoral range lands of Ethiopia are located around the peripheral or the outer edge of the country, almost surrounding the central highland mass. The areas are classified as marginal arable and non - arable land and covers about $62 \%$ of the country's land area. Most of these areas are below 1500 meters above sea level with the southwest and the south eastern areas having an altitude of around 1000 meters, and the south eastern and south western areas rising up to 1700 meters and above (Kidane, 1993). They are also mostly characterized by lowland plains and have a relatively harsh weatehr with low, unreliable and erratic rainfall and usually high temperature. These lowlands have sparse vegetation composed mainly of grasses, bushes, shrubs, small trees and bare land with a small amout of surface water and are sparsely populated with few permanent rural settlements of the indigenous pastoral population (UNDP/RRC, 1984).

These lowlands are predominately pastoral with most people largely depending on livestock rearing for their livelihood. These are the homes of $26 \%$ of the total livestock (Coppock, 1994). Even though a higher abundance of livestock is found in the highlands, the lowland livestock play a considerable role in the national economy. Lowland breeds of cattle and sheep make up over 90\% of legal export of live animals, and in the mid 1980 live animals contributed about $12 \%$ of gross export revenue, second to coffee (Coppock, 1994). The same report further suggested that lowland cattle provided around $20 \%$ of the draught animals for the highlands.

The southern Ethiopia rangelands are one of the drier areas assumed to be the best cattle rangeland in the country and even in Africa (JEPSS, 1983; UNDP/RRC, 1984). The Borana plateau, where the southern rangeland lies, covers about 95, $000 \mathrm{~km}^{2}$ of the national area (JEPSS, 1983; UNDP/RRC, 1984). The southern rangelands lie west of Genale River and east of the Segen River. Its Southern limit goes all the way to the Ethiopia-Kenya and Ethiopia-Somalia borders leaving out cultivated and high forest areas to the north. Most of the land falls within the altitudinal range of 1000-1500 m.a.s.l gently sloping down south and southeast to the border. However, there are occasional mountainous areas rising to $2000 \mathrm{~m}$, particularly the Yabelo-Mega plateau. Along the lower basin, the Dawa River flows southeast to join the Genale River at the Ethiopia-Somalia Border (JEPSS 1983; UNDP/RRC, 1984).

Now a days, degradation of range resources has been a serious problem due to numerious causative factors such as climate change, increasing in human and cattle population, and range resource management regimes. As to the knowledge of authors, eventhough pastoralism contribute a lot for environmental,social and economic development of the country,so far no broad review available regarding water and pasture management in pastoral area of southern Ethiopia. This review aims to fill this gap. Therefore, the aim of this review paper is to have better understanding of the challenges and mamagement of common resources of pastoral area in southern Ethiopia.Thus,this paper particularly focused on pasture and water resources managements. 


\section{Litrature review}

\subsection{Definitions and Concepts of Commons}

For past two-decades the concepts of common property have been highly interprated wrongly. It is an organized possesing arrangements within which management rules are formulated, group size is known and enforced, payment exist for co-owners to follow the accepted institutional arrangements, and penalty work to insure compliance but it is not free to all as it has been described (World Bank, 1989). It can be additionally defined as follows.

Common resources are those resources that can be used commonly by different users because of difficulties in claiming or enforcing exclusive rights, or because they are so scarce or indeterminate that it is not worth doing so. As invers to open access resources, common property resources are look after by institutions who claim ownership and management rights over the common resources on behalf of a known group. These rights include the right to rrefuse access to those who are not belongs to the group, and to regulate the unwise use of the resources by members. Common property systems generally include all community based or customary resource management systems (Hesse \& Trench, 2000).

For the past decades literatures on common resources can be summarized by the sentence "everybody's property is nobody's property.". When a given natural resource is commonly accessible to more than one user, the access is said to be a free to all, users competing with eachother for a greater stake of the resource to the detriment of themselves, the resource, and society at large. The idea of common resources exploitation have been applied many resources including fisheries, grazing lands, forestry, water, oil, air, campgrounds, and even highways and the radio spectrum. Common property system is widely blamed for a host of social problems including resource depletion, pollution, dissipation of economic surplus, poverty among resource users, backwardness in technology, and misallocation of labor and capital (Wantrup \& Bishop, 1975).

\subsection{Social organization and customary institutions for pature and water management}

Ethiopia's Borana have some of the most detailed water control and management systems in the country. Regarding access to pasture, management is traditionally the obligation of territorial units (deedhas), the boundaries of which are not fixed and changeable depending on the availability of resources. A complex customary administrative structure, the gaada, administers the deedhas, according to the customs and laws of the Borana (Tache, 2000).

Regarding access to water, which in turn influences which pasture can be used when and by whom, access is determined on different bases depending on type and season. For ponds and pools that fill up in the wet season, a contribution to maintenance usually secures access. Construction, maintenance and cooperation around the use of ponds and surface catchments is usually undertaken at the level of the reera, a smaller territorial scale than the deedha - members are encouraged to use ponds in their own reera to wise using neighboring resources (Tache, 2000). When water levels in ponds are observed to be reduced too fast, precedence is given to the domestic use of the closest ollas (groups of households with associated cattle enclosures) and adult cattle are excluded in favors of calves. If necessary, even calves will be excluded and must be moved to other ponds or wells (Bassi, 2005).

Traditional wells are critical sources of dry season water and belong to clans, as notably large labour inputs are needed for both construction and extraction of water. An individual, called the konfi, initiate the digging of a well, becoming father of the well, or abbaa ellaa, securing access priority and decision making privileges rather than absolute ownership. Though the konfi has decision making right with regards the well, he is closely notice by clan elders who make sure that he makes decisions accourding to the customs and laws of the Borana (Helland, 1980). The konfi enrol assistance from his own clan, from other clans and lineages in terms of obtaining the labour and the cattle necessary to sustain the digging crew during the construction work. The provider clans thereby also earn access rights to the well. Borana who did not contributed to well construction may also be extended temporary access rights in times of need. Traditional regulations determine access to the well in terms of the day and the position in the queue for that day, supervise by the father of turns' (abbaa herregaa), who is nominated by the abaa ella. The number of positions in the queue rely on the amount of water available and the rate of water seepage (Bassi, 2005).

\subsection{Policies, laws and strategies for water development}

A numerous of national development policies and laws have implications for water development in pastoral regions, including the Poverty Reduction Strategy Paper (PRSP) (2001); PASDEP (2006) and the Federal Rural Land Law 2005. These reflect evolutions in thinking. In the last 10 years the debate has changed dramatically, from adequte mention of pastoralism, and when mentioned cast in a negative light and in need of an examine to increase production through technical fixes, to highlighting mobility, the importance of customary institutions and supporting livelihoods. But, these policies and laws also reflect the persistent paradox at the heart of the policy direction regarding pastoralism: whereas in the short term government aims to support customary pastoral production systems, the long-term aim is on voluntarily settling pastoralists by providing livelihood diversification 
opportunities, in particular fixed on irrigation agriculture.

Moreover, policy relating to water development may worse the sedentarising effect. For instance, MoFA's 2008 Draft Policy Statement for the Sustainable Development of Pastoral and Agro-pastoral Areas of Ethiopia states that in the long-term, the government visualize a stable pastoral and agro pastoral community via facilitation of gradual and voluntary transition towards permanent settlement, to a great extent along the perennial river banks (MoFA, 2008). In what ever way, many professionals in the field believe that sedentarisation will seriously exacerbate the challenges facing pastoral livelihoods. Further, tenure security for pastoral communal rangelands also does not seem high on the national or regional agenda.

Where the documents refer to what can be regarded as best practice principles, there is seldomly a clear indication of how these are to be put into effect (e.g. increasing understanding of communal range management strategies, as emphasised in the PASDEP). With regard to participation, development of the PRSP and PASDEP involved discussion with pastoralists, but in both cases these do not seem to have strongly influenced the final documents (Pastoralist Forum Ethiopia, 2009). Regarding the Federal Rural Land Law, a principal disapproving is that the emphasis on private landholdings pay no attention to the rationale of traditional communal landholding, which goes against the federal Constitution (Abdulahi and Adenew, 2007).

\subsection{The pastoral livelihood strategy}

Within the large covering rangelands of these regions, scarce and variable rainfall control the presence or absence of pasture and water on which livestock depends. The rainy season allow pastoralists to disperse over a wide area, while the grazing range contracts in the dry season around permanent water sources such as rivers or groundwaterfed wells. The high degree of mobility during grazing allows dry season grazing areas to a normal state of health between seasons and contributes to rangeland health by encouraging vegetation growth, fertilizing the soil, supports seed dispersal to keep pasture diversity and keep from happening bush encroachment (Hesse and MacGregor, 2006). Comparison with areas around permanent settlements reveals higher levels of degradation than in open rangeland where mobile pastoralism.

The tragedy of the commons hypothesis, which put forward that individual herders eventually overgraze and reduce the quality of open access pasture by indiscriminately increasing herd size (Hardin, 1968), does not reflect reality in the rangelands. In fact, access is not 'open', but rather it is controld through negotiation and reciprocity within a system of communal land tenure. Groups are oftentimes associated with specific territories which contain critical natural resources such as grazing land and water resources, but membership, and boundaries between these territories, is often not fixed to accommodate mobility in times of scarcity (Mwangi and Dohrn, 2006). The variable location of rainy season and dry season pastures from year to year increases the need for such a flexible system. Traditional institutions let different clans or groups to be represented in decision-making concerning access to land and water (Gomes, 2006).

The prolonged pastoralist livelihood strategy in most of the arid lowlands attests to its rationality and flexibility, but mobility is essential. According to devereux (2006) where mobility is obstuctes, pastoral households are more economically and food-secure than their settled counterparts, and that many pastoral settlements in Ethiopia were partially or completely abandoned in the droughts of 2004 and 2006. Little et al. (2008) made a similar conclusion, emphasizing that households are less likely to lose their livestock assets and become foodinsecure if they remain mobile. Moreover , tragedy of the commons thinking greatly influenced approaches in the early years of development in Ethiopia's lowlands, and continues to do so.

\subsection{Technical approaches to rangeland management}

Different International NGOs, such as CARE, SCUS, Action for Development (AFD) and SOS Sahel, are working to improve rangeland management in Borana where there are issues of bush encroachment and land degradation.

Encroaching woody species are recognized as reducing grazing land through colonizing rangeland, as well as surpassing herbaceous grasses for nutrients, thus reducing grass cover and altimately feed for livestock. The rapid reproduction of woody species can be seen as a cause of land degradation. Changes in grazing patterns, due to vulnerabilities which constrict rangeland usage, appear to be exacerbating the effect and heavy grazing in areas seems to encourage further bush encroachment. While the spread of woody plants are a symptom of wider vulnerability issues, the net result is that they further the effects of fragmenting rangelands. Technical approaches have thus been geared towards counteracting the proliferation of these plants and encouraging grass growth through the following main approaches: 1) Prescribed fire, 2) Hand cutting woody species, 3) Enclosures (kallos), 4) Reseeding 5) Differed grazing

\subsubsection{Prescribed Fire}

Fire is the main environmental driver that controls the function of savannah ecosystems. It was a tool used by Borana pastoralists to suppress bush growth by killing encroaching woody species. Suppressed by the government in the early 1970s, it is now being slowly re-introduced (Angassa and Oba, 2009). Conversations with pastoralists revealed that burning also gets rid of ticks, which infest cattle, and produces sweet grass for 
animals (Skinner, 2010).

Borana pastoralists believed that the ban on fire had adversely affected the overall productivity of the rangelands (Skinner, 2010). Bearing these factors in mind, NGOs are re-introducing burning as a rangeland management technique through 'prescribed fire' - the controlled and managed application of fire to defined units of grassland.

However, some of the long-term consequences of fire are drying of the land, reduction of plant cover and loss of nutrients (Demeke, 2009). Moreover, fire treats the symptoms of land degradation rather than the underlying causes, thereby becoming more and more necessary since the problem will persist (Hatfield, 2009). Practical considerations, mentioned by pastoralists and development staff alike, are that the fuel load (ground cover) is now so patchy that it can be difficult to get a fire started and maintained. Moreover, the proliferation of villages in the area could constitute a hazard should fires get out of control.

As a tool on its own, fire may not have long-term sustainable benefits, but it is an approach favored by pastoralists and has worked well as a short-term, repetitive strategy in the past. Taking this into account, one option is to combine prescribed fire with grazing animals, following a period of rest. This concedes even more with traditional pastoralist practice and allows the fertilization and conditioning of the soil through hoof action and dung, thus encouraging re-growth. In a practical study conducted to compare the merits of different rangeland management systems, Angassa found that combining fire with grazing achieved a restoration of herbaceous plant diversity (Angassa, 2007). Precautions would have to be taken however to ensure that burning is kept within prescribed areas as not all areas are appropriate (Skinner, 2010). There is no enough knowledge on the impact of fire on unwanted bushes and desirable grasses as there hasn't been sufficient monitoring of its effects. It is therefore an area requiring further investigation in order to determine its suitability for the changing ecology of today's Borana rangelands.

\subsubsection{Hand cutting woody species}

Hand clearing woody species involves pastoral communities in physically cutting down unwanted trees. This method is more discerning than fire since trees can be selectively cut, rather than indiscriminately burned - some trees e.g. the shepherd's tree, are useful animal fodder. Prior attempts to address bush encroachment in this manner involved intensively cutting large areas of bush. This method, however, has been found to have limited impact since most of the invasive species re-sprout after cutting (Demeke, 2009).

After 15 years of experience following this method, SOS Sahel has given up since, 'plots which were cleared then are now again overgrown with acacia' (Skinner, 2010). Some other drawbacks to the method include Angassa's observation, that since the method is labour intensive and trees have to be regularly cut, it would only work for land which was easily accessible. For practical purposes, therefore, tree cutting wouldn't be a method which worked for vast swathes or rangeland, but rather for designated areas near settlements which could serve as reserves for the weak or sick animals (Angassa, 2007).

\subsubsection{Enclosures}

In response to changes in land use, the Borana revised the traditional system of grazing reserves specifically set aside for calves and weak animals (kallos). These tended to be open pasture in key grazing landscapes such as hill tops and valleys and were set aside for calf and weak animal grazing through community consensus. Some of these areas have been converted into crop land, but others have been preserved by households as traditional calfgrazing reserves. In order to protect them, the areas have been enclosed by perimeter fences (Oba and Angassa, 2008).

Drawing from these practices, NGOs such as CARE and SCUS, have helped establish new enclosures by facilitating village level meetings to agree on land which can be put aside for this purpose. The land is then enclosed with thorn fences to prevent un-condoned grazing. By reducing grazing pressure the land can 'rest' and recuperate. In order to rid the area of woody species, the area is also usually hand cleared of trees (Skinner, 2010).

A study of the long-term consequences of treating land in this way also revealed that the proliferation of bush encroachment is a major threat in these enclosures over time, as compared to more regularly grazed rangelands (Angassa, 2007).

Enclosures help protect land to a certain extent, but as with the other approaches, are more effective when combined with other techniques such as bush clearing. In order for the enclosures to be sustainable over time they also require careful management (Skinner, 2010).

\subsubsection{Reseeding}

Reseeding involves collecting seeds from existing grasses and then sowing them on bare ground. This approach has had only minimal attention and results to date. Positive results came from one experiment conducted by the Oromia Agricultural Research Institute, but a similar attempt by Action for Development proved unsuccessful. This method assumes that the dearth of grasses is due to a lack of seeds. Often, however, seeds are readily available and are still in the ground, but they do not have the right conditions in place to grow. The reseeding approach would involve ground preparation using fertilizers and ongoing nurturing, as well as encouraging pastoralists to collect enough seeds in the growing season to sow the land when needed - one obstacle which 
Action for Development ran into since the concept was still new to pastoralists. This approach could be considered in particularly barren areas, but would be labor intensive, not particularly cost-effective and would have to first be taken on board by the pastoralist community (Skinner, 2010).

\subsubsection{Deferred Grazing}

This is the easiest and most effective range improvement and rehabilitation method that can be practiced if the idea is accepted and the set regulations are properly implemented by the beneficiaries. The longer the beginning of grazing on a range is delayed, the better the opportunity exists for new plants to become established and for old plants to gain vigor. If grazing can be deferred (rested) every few years, forage plants will have better opportunity to reproduce. Therefore, resting pasture land periodically from 3 to 12 months depending on the magnitude of the spoiled area and then allowing controlled grazing can improve forage productivity. Hence, the resting period should extend throughout one complete wet and dry season grazing period every 4 or 5 years. Since SNRS is vast and constitute diversified range vegetation, this coping strategy will be one of the best options (PFE et al., 2010).

\subsection{Challenges to pastoralism and the rangelands}

In spite of the positive impact of pastoralism to pastoralist livelihood, the economy and rangeland health, the following realities cannot be over looked:

- Population increase, including via the resettlement of highland populations to the lowlands, who will likely require livelihood options based on agriculture;

- Stubborn encroachment of prosopis juliflora;

- Excision of grazing areas for irrigation, especially dry season pastures near to permanent water sources;

- Further demarcation and enclosure for uses such as national parks, private grazing and crop cultivation (including by pastoralists, as well as immigrants and refugees);

- Increased sedentarisation and the proliferation of water points, which promote settlement;

- Poor rangeland management and continued degradation.

- Lack of concern for IK

- Natural factors: climate change and environmental degradation

With powerful underlying drivers, including climate, conflict, poverty and demographics, these factors contribute to shrinkage of land available for grazing and reduced opportunities for mobility. Among Ethiopia's pastoral communities, the effects are decreased per capita holdings of livestock, an increased trend towards agropastoralism (Yemane, 2003) and more pastoral dropouts who seek petty labour in permanent settlements (Desta et al., 2008).

Pastoralism is not the only livelihood in the rangelands, and multiple needs and priorities as well as livelihood strategies must be explored fully and impartially to enable enhanced national economic growth without compromising sustainable livelihoods. This importantly includes mobile pastoral livelihoods. The policy response to date, however, has been incoherent and on the whole favors settled forms of livelihoods, which puts certain livelihoods at a disadvantage from the outset National government leans towards promoting settlement as a longterm objective, believing this to be the only lasting and sustainable solution to protect livelihoods. This attitude is shared by some donors, NGOs and development agencies. Others staunchly support mobility. Many NGOs continue to make water development decisions based primarily on technical considerations with insufficient consideration of livelihood dynamics and the risk of increasing sedentarisation. However, both NGO and local government staff recruited from pastoral areas have first-hand knowledge of the need for livestock mobility and seasonal recovery of rangelands.

\subsection{The Current Condition of Borena Rangeland}

The Borana rangeland is in its deteriorating state or its productivity is declining from time to time. And, the major factors for these problems would be; bush encroachment, rainfall scarcity, increase in the number of livestock and consequent overgrazing, expansion of farmland, proliferation of water point and the like (skinner, 2010). Helland (2000), in his study indicated that Borana pastoralists were in favorable position to develop efficient system of natural resource management but now in transition state in which external influences have started to shape their strategies (cited in Homann 2008). Scoones 1999, reported that the Borana rangelands are considered highly productive for a dry land area (cited in Watson 2003). But,according to (Skinner,2010)there are different indicators of decrease in rangeland productivity as follow:

$>$ Increased frequency of animal death. The death of animals is not a recent phenomenon; it is as old as the rearing of cattle in the area. In the past animals death was less frequent and a few numbers of animals used to die because of cattle diseases or because of severe dry season. But many others were resistant even to very harsh condition because of availability of sufficient fodder. Even in extreme cases animals' death occur in the late dry season. Currently, however, the death of animals is more frequent and takes places in the early period of dry season.

$>$ Decrease in milk yield is another indicator of decline in rangeland productivity. Hendy and Morton 
reported that on the natural rangelands performance of livestock depends on the quantity and quality of forage available for animals (Hendy and Morton, 2001). According to the skinner milk yield per lactating cow is a good measure of rangeland productivity. Borana used to subsist on the animals products, mainly milk, only without having other supplementary means of livelihoods. In the past if a given family has two lactating cows for example, the milk yield from these two cows is enough to feed the entire family members. But now, whatsoever the number of lactating cows possessed, the milk obtained from them cannot support the owner household and they need additional of subsistence either from farm or through purchase which is the common feature of almost all Borana.

$>$ Decrease in reproduction rate is another measuring factor of range productivity. Participants reported that livestock reproduction rate is declining form time to time and is currently taking place at a very lower rate than it was in the past. In the past animal

Breeding took place at faster rate and even sometimes faster than needed as a result of high range resources availability. Even herders separate female and male animals to avoid mating. Now a day, however, the situation is reverse as animals breeding rate is decreasing with decline in rangeland productivity (Skinner, 2010)

Generally, rangeland management is currently facing several challenges partly human induced and partly naturally occurring problems. Consequently, the productivity of Borana range land has been deteriorating from time to time as a result of the combined effect of the above noted challenges. These make range resources management and utilization difficult and put Borana livestock at risk in the long run.

\subsection{Introducing Holistic Management}

Holistic Management (HM) addresses the problem by looking to the broad range of factors which affect ecosystem health and trying to re-establish a balance by using a variety of tools in combination - animals, resting land, time, and people. The HM concept was coined by Zimbabwean, Allan Savory who spent years studying the problem in Africa. From case studies he made of land degradation across the globe, he suggested that the one common denominator to the problem was human management and decisions (Savory, 1999). He argued that in degraded landscapes the fundamental processes which drive our ecosystems have in one way or another been disruptedthe water cycle, the mineral cycle, energy-flow and the dynamics between living organisms in a specific environment. With proper understanding of ecosystem dynamics, these interactions can be re-established.

The main contribution of Holistic Management is to aid practitioners and pastoralists to apply again the principles under modern conditions and reestablish this dynamism which is so important to rangeland health. Holistic Management doing this in three ways:

It confirms the principles for optimal grazing, which lay the technical basis for transforming degraded lands back to highly productive lands. The analogy to illustrate the point is of the Serengeti migration where 1.5 million wildebeest and 1 million zebra, 'act as combine-harvester, plough, seed-planter, soil aerator and fertilizer - at minimal financial cost' (Hatfield, 2009). The mouths, hooves and dung of animals are thus all seen as tools which can contribute to improving range condition and help with the fundamental ecosystem processes e.g. when animals are bunched, hooves churn up hard soil allowing for better aeration and water infiltration and thus encourage the water cycle.

Adapted to livestock, the management role is to get animals to the right place at the right time, in the right way and for the right reason. This involves a management plan which takes account of temporal and movement. Animals are managed so that their impact encourages an environment which is conducive to grass growth and inhibiting to the spread of woody species. Temporal must take account of how much animal impact a piece of land needs in order to recuperate water, mineral, energy and system-dynamics. Movement means that animals are rotating according to a grazing schedule, much as crop rotation, in order to give a piece of land first the necessary 'animal treatment' followed by a period of rest. The details are technical, but the main point is that the concept encourages pastoralists to graze their herds bunched together in a defined area, before moving them on to a new grazing areas according to specific timings - a concept familiar to pastoral communities in Borana for whom it echoes their own traditional rangeland management techniques.

2. It gives insight into the effects of the other tools being used in rangeland management on the health of the ecosystem e.g. the long-term disadvantages of fire-maintained rather than animal-maintained grasslands, the negative impacts on rangeland productivity by excluding grazers, and the tendency of perceived solutions such as bush clearing to treat the Symptoms of land degradation rather than the underlying causes (Hatfield, 2009). While tools such as fire can certainly be incorporated into the HM plan, it should be done in balance with other ecological considerations e.g. how much animal fertilizer the land should then receive in order to recuperate.

3) HM uses a simple decision-making framework, which emphasizes the management basis for applying grazing principles (Hatfield, 2009). The most challenging aspect of HM is that it requires a considerable degree of management skill, time and effort. This can be challenging in communal settings where cooperation, joint planning and multiple managers are required. However, for the Borana, the customary management system 
involved many of these principles and so again the concept is a familiar one.

\section{Conclusion and Recommendations}

Now a days the southern Ethiopia pastoralist operate over a circumscribed area of increasingly degraded rangeland suffering from increasing bush encroachment. The rangelands are shrinking through various factors including population growth, agricultural encroachment, land degradation, amongst others by scarce natural resources (i.e water and pasture). Smaller grazing areas mean that the southern Ethiopia pastoralists are slowly having to abandon the customary, ecologically balanced management system which reduced risk by operating over a large area and gave grasslands time to recover. Therefore development interventions which can assist to reverse the process of degradation and which aim to re-establish healthy grasslands are one of the valuable strategies used to improve the resource base for their livestock raring. Moreover, both formal and informal institutions have been playing critical role in management of commons (water and pasture). But, this excellent system of resource management have been weakened gradually with influence of different external factors like; state intervention, privatizations of communal lands and marginalization of indigenous knowledge of community. The technical approaches to rangeland management, particularly prescribed fire, cutting trees and enclosures, are providing some relief to the problems of rangeland degradation. These methods are also preferable since they do not introduce new systems of management into the system, but draw from existing practice.

Based on the review made herein we have suggested some future perspectives that need to take into account.

$\checkmark$ Understand the rangeland context for effective planning

$\checkmark$ Secure sustainability through capacity-building, user contributions and use of customary institutions and practices

$\checkmark$ Collaborative link among researchres, managers and local land users to improve science, management and rangeland ecosystem.

$\checkmark \quad$ National government should adopt policies for the conserved use of rangelands.

$\checkmark \quad$ Indigenouse knowledge on water and pasture mamagement, and their utilization should be encoraged and the way to work with scientific methods has to be put aside.

$\checkmark$ Conducting further studies to see how effective combined management techniques can be applied e.g cutting trees followed by burning.

$\checkmark$ Developing thinking which considers the whole (economic, social and environmental aspects).

$\checkmark$ Applying EIA before launching any development project.

\section{Reference}

Abdulahi, M. and Adenew, B. (2007) 'Research and Advocacy on Land Use Right and Tenure Systems in Pastoral Areas of Ethiopia'. Report for PCAE.

Angassa, A. (2007). The Dynamics of Savanna Ecosystems and Management in Borana, Southern Ethiopia. PhD Thesis, NORAGRIC, Norwegian University of Life Sciences.

Yemane, B. (2003) 'Food Security Situation in the Pastoral Areas of Ethiopia'. Oxford: Oxfam GB.

Angassa, A. and Oba, G. (2008). Herder perceptions on impacts of range enclosures, crop farming, fire ban and bush encroachment on the rangelands of Borana, southern Ethiopia. Human Ecology 36, pp. 201-215.

Bassi, M. (2005) Decisions in the Shade: Political and Juridical Processes among the Oromo-Borana. Trenton, NJ: Red Sea Press.

Hesse, C. and Trench, P. (2000). Who's managing the Commons? Inclusive management for a sustainable future. Nottingham: Russell Press, 2000.

Wantrup, C. and Bishop, R. (1975). Common property" as a concept" in natural resources policy. Natural resources journal, vol. 15, pp713-727, 1975.

Coppock D. Layne (1994). The Borana plateau of Southern Ethiopia: Synthesis of Pastoral Research, Development and change, 1980-91. International Livestock Center for Africa, Addis Ababa, Ethiopia.

Desta, S., Berhanu, W., Gebru, G. and Amosha, D.(2008) 'Pastoral Dropout Study in Selected Woredas of Borana Zone Oromia Regional State'. Addis Ababa: CARE Ethiopia.

Devereux, S. (2006) 'Vulnerable Livelihoods in Somali Region, Ethiopia'. Research Report 57, Brighton:IDS.

Federal Democratic Republic of Ethiopia (2007) 'Summary and Statistical Report of the 200 Population and Housing Census'. Addis Ababa: Population Census Commission.

Hardin, G. (1968) 'The Tragedy of the Commons'.Science 162(3859): 1243-1248.

Gomes, N. (2006) 'Access to Water, Pastoral Resource Management and Pastoralists' Livelihoods: Lessons Learned from Water development in Selected Areas of Eastern Africa (Kenya, Ethiopia, Somalia)'. Rome: Livelihood Support Programme, Food and Agricultural Organization.

Hatfield, R. (2009). Managing Holistically. In ELMT/ELSE Newsletter 2.

Hesse, C., and MacGregor, J. (2006) ‘Pastoralism: Drylands, Invisible Asset?’ Issue Paper 142. London: IIED.

Homann, S. (2008). Towards Endogenous Livestock Development: Borana Pastoralists' Responses to 
Environmental and Institutional Changes. In Human Ecology 36 (4), pp. 503-520.

Kassahun, A., Snyman, H.A. and Smit, G.N. (2008) 'Impact of Rangeland Degradation on the Pastoral Production Systems, Livelihoods and Perceptions of the Somali Pastoralists in Eastern Ethiopia'. Journal of Arid Environments 72(7): 1265-1281.

Little, P., Mcpeak, J., Barrett, C.B. and Kristjanson, P. (2008) 'Challenging Orthodoxies: Understanding Poverty in Pastoral Areas of East Africa'

McCarthy, N., Kamara, A. and Kirk, M. (2001) 'The Effect of Environmental Variability on Livestock and LandUse Management: The Borana Plateau, Southern Ethiopia’. Nairobi: IFPRI, USA and ILRI.

Mwangi E. and Dohrn, S. (2006) 'Biting the Bullet: How To Secure Access to Drylands Resources for Multiple Users'. CAPRi Working Paper 47. Washington, DC: IFPRI.

Ministry of Federal Affairs (2008) 'Draft Policy Statement for the Sustainable Development of Pastoral and Agro Pastoral Areas of Ethiopia'. Addis Ababa: MoFA.

Oromia Water Works Design and Supervision Enterprise (2009) 'Pilot Phase Land Use Implementation Plan'. Draft. Oromia: OWWDSE, Oromia Regional Government.

Pastoralist Forum Ethiopia (2009) 'Pastoralist Perspectives of PRSP'. Addis Ababa: Pastoralist Forum Ethiopia.

UNDP (United Nations Development Programme). 2003. Why the drylands? UNDP-Drylands Development Centre, Nairobi, Republic of Kenya: UNDP.

RECA (Economic Commission for Africa). 2000. Safeguarding Life and Development in Africa. A Vision for Water Resources Management in the $21^{\text {st }}$ Century. Africa Caucus Presentations. Second World WaterForum, March 18, 2000. The Hague, the Netherlands. Addis Ababa.

Scott-Villiers, A. (ed.) (2006) 'Peace, Trade and Unity: Reporting from the Horn of Africa Regional Pastoralist Gathering, Qarsaa Dembii, Yabello, Ethiopia'. UN OCHA Pastoralist Communication Initiative.

Skinner, 2010 Demeke, F. (2009). Improving the Rangeland in Borana, Ethiopia. In ELMT/ELSE Newsletter 2.

SOS Sahel Ethiopia (2008) 'Pastoralism in Ethiopia: Its Total Economic Values and Development Challenges'. Report for IUCN-WISP.

Tache, B.D. (2000) 'Individualising the Commons: Changing Resource Tenure among Borana Oromo of Southern Ethiopia'. Addis Ababa University.

Watson C. and Catley A. (2008). Livelihoods, Livestock and Humanitarian response: the Livestock Emergency Guidelines and Standards. HPN Network Paper 64, London: ODI. [Online]. Downloaded on 10 December, 2009

from:http://www.reliefweb.int/rw/lib.nsf/db900sid/JBRN7NNE35/\$file/odihpn_dec08.pdf?openelement

World Bank (1989). The Management of Common Property Natural Resources Some Conceptual and Operational Fallacies. Washington, D.C.: Libraryof Congress Cataloging-in-Publication Data, 1989.

World Bank (2008) 'Pastoral Community Development Project II Report No:43472-ET, Ethiopia'. Project Appraisal Document. Addis Ababa: World Bank. 